\title{
Development of guidance and counseling module on self- regulation of students in social relations
}

Ita Karina Bancin ${ }^{1}$, Mudjiran $^{2}$, Rusdinal $^{3}$

${ }^{123}$ Universitas Negeri Padang

\begin{tabular}{l}
\hline \hline Article Info \\
\hline Article history: \\
Received Apr $10^{\text {th }}, 2019$ \\
Revised May $20^{\text {th }}, 2019$ \\
Accepted Jun $15^{\text {th }}, 2019$ \\
\hline
\end{tabular}

\section{Keyword:}

Self Regulation

Social Relations

Module

\begin{abstract}
Self regulation is one way to improve students understanding of good social relations. This research aimed to plan module and to describe the level of applicability the guidance and counseling module on student self-regulation in social relations. The method used was ADDIE model development. The subjects of the research were three experts and three counselors. The used and practicality the module used instruments in the form of questionnaire. This research employed the research product trial. The data of the research were analyzed by using the Coefficient Concordance test of Kendall's W. The result of the research showed that the module on self-regulation of students in social relation was effective to be used by counselor. The practicality degree of the module on self-regulation of students in social relations was highly valued for use by students.
\end{abstract}

(C) 2018 The Authors. Published by Redwhitepress.

This is an open access article under the CC BY-NC-SA license (https://creativecommons.org/licenses/by-nc-sa/4.0/

\section{Corresponding Author:}

Ita Karina Bancin

Universitas Negeri Padang

Email: bancin37@gmail.com

\section{Introduction}

The school is one container forming students' attitudes and behavior. Attitude and behavior are formed from the environment. Sometimes students will find themselves as individuals who do not need other people when the existing social relations are not under what was expected. It requires a conducive environment in shaping goodsocial relationsfor students in order to improve their self-regulation in social relations.

The ability of self regulation in the form of social relations, students not only have a good academic scores but also can establish social relations. By doing so, they will not experience problems in their social life such as getting shunned by others as arrogant with good academic ability or inability to establish good communication with others.

In their research, Khuziakhmetov, Shafikova, and Kapranova (2015) state that the relevance of the study is conditioned because social relations from a school graduator require not only the subject specific competences, but Also the ability to build interpersonal interaction is based on moral norms. The opinion can be interpreted that the social relationships in school not only build academic ability but also build interpersonal interactions that are based on moral norms.

Walgito (2001) states that social relationship is a reciprocal relationship between someone and others, based on the mutual influence and awareness to help each other. Then, Ahmadi (2007) states that social relation is an interaction between individuals or more, the behavior of one individual affect, alter or improve the behavior of other individuals or vice versa. Thus, social relation is also referred to as a social interaction in which there are the interplay between two or more people. 


\section{Development of guidance and counseling module on self-regulation of students in social relations}

Based on the explanation above, it can be understood that every individual must have social relations because human beings were created as social beings who would not be separated from social interaction or social contact with other individuals or groups.

Having good relationship requires self-regulation to shape behavior in social relation. This is in accordance with the opinion of Suhendra, Neviyarni and Ahmad (2016) who state that association of students in school and out of school affects students in reaching achievements, therefore it should be setting yourself up for students to be able to focus to reach his goal and is not affected by the environment good. Then, with the self-regulation / self-regulation a student will be able to form good relationships in the association at school. Furthermore, Feldman (2009) declaresthat the basis of self-regulation is the socialization that connects all developmental domains: physical, cognitive, emotional, and social. Thus, in the formation of social relationships necessary self-regulation. In the process, self-regulation has relevance to the field of education is the field of understanding of how learners to train their own behavior that will result in the increase of individual success in education and also affect the success in social relationships. This is in line with Galinsky' opinion (in Florez, 2011), with the occurrence of self-regulation, one would be able to organize your thoughts, emotions and behavior of people for success in school, work and life.So, each individual has the ability to organize themselves and have the responsibility of each to always be on the path to goodness as an effort to achieve its objectives in an educational setting.

Self-regulation means the ability to control their own behavior. According to Schunk and Zimmerman (in Susanto, 2006), self-regulation is the use of a process which activates thoughts, feelings, and behaviors are constantly in an effort to achieve the goals set. Then Hendri (2008) argues that individuals perform this selfregulation by observing, judging, reward or punishment for his behavior, Thus, self-regulation is an individual's ability to regulate itself through thoughts, feelings, andbehavior mutually continuous with the individual's ability to observe, consider and give rewards to their own behavior.

According to Susanto (2006), the ability of self-regulation can not grow by itself. It takes a conducive environment so that individuals can develop the ability of self-regulation. Then, Winne and Boekaerts (in Susanto, 2006) state that everyone has the effort to regulate itself in various ways to achieve the goal difference is the effectiveness of self-regulation. It is in line with Clearyand Zimmerman (2004) research, self-regulation is used to empower students to get positive actions by assessing their' beliefs, using strategies in achieving the goals and making their own rules.

Exposure to the above concluded that students in achieving good social relations must have a good selfregulation as well. To achieve good self-regulation in social relations influenced by not only myself but also affect the environment that supports student success in the regulation.

Inability to regulate themselves in social relations can cause a variety of negative influences in a person. This is evidenced in the results of research conducted Raffaeli et al (in Chairani, et al, 2010) which reveals the inability to regulate themselves cause a person to become addicted to alcohol and drugs, are not able to adapt to the environment and also make children vulnerable to risks despite not being in a risky environment triggered a psychological disease. Instead, the students' skills in self-regulation can improve the spirit of the students in conducting relations with social communications to both the teacher and peers.

Both the above results can be interpreted that the students who are unable to regulate themselves tend to be affected in a negative social relations. Instead, students are able to regulate themselves well potentially good social relationships, for example, students can take advantage of the environment well when encountering difficulties, students will be asked for help from the teacher or a friend to resolve the difficulties in doing the task. Students are able to set up the environment to better show the students that have the ability of selfregulation.

Students ability to self-regulation can be seen from the relationships. How students build relationships with teachers, peer relationships, or relationships with individuals who are under age.Self-regulation can also develop an understanding of the individual in social relations. Individuals who are able to regulate themselves well must have good social relationships in their daily lives. So, with the self-regulation of this, students will know and understand what behaviors are unacceptable in social relations, so that individuals can establish an attitude in social relationships.

Students who have problems in social relationships can be seen by its ability to regulate themselves. Students' ability to self-regulation is shown by their conduct in the environment. Based on observations in high school UNP Development Laboratory in Padang found the students who come late to school, not completing school assignments, do not have a clear study plan, and yet have self-awareness. In addition there are students who disturb your friends by mocking, those students who tend to shut down, the students are difficult to communicate with peers, students who prefer silent and passive by his friend, talking disrespectful to the teacher, and when the student learning is not have self-confidence.

The above problem shows that the importance of self-regulation for students to engage students in a good social relations so as to achieve a positive development in education. Students who have good selfregulation, meaning the ability to regulate their own behavior standards and set a goal to be achieved. Good 
self-regulation is also characterized by its ability to observe their own behavior, so know the part of yourself that must be corrected.

The research results found by Susanto (2006) states that success in living things including good achievement in education and other fields are not determined by the IQ (Intelligence Quotient) only, but one of them is the ability of self-regulation in social relations.

With regard to the issue of self-regulation in social relations, it can be seen that the ministry counselors in enhancing the ability of self-regulation of students must be optimized so that the students' social relationships lead to positive things. To improve social relationships need assistance counselor to overcome them. In this regard, it is worth holding counselor efforts in developing guidance counseling care practices in the social field. In accordance with the Regulation of the Minister of National Education no. 20/2008 counselor task is to support the personal development of the students according to the needs, interests, talents and personality. Specifically to help learners to student success in social development to be able to interact socially with people around. So that students have good social relationships through self-regulation abilities of students. In this case, the researchers are interested in developing learning media in the form of modules that can be used counselors in providing services. This is because by using the module canincrease the motivation of students, so that students can learn on their own activities without the presence of faculty directly (Depdiknas, 2008). In other words, students can learn independently and active so expect students acquire new knowledge and understanding in accordance with the objectives to be achieved.

The media is also often called as self-instructional material that teachers do not have to directly teach or teach something to his students face to face, but enough to give the module. In order to help counselor in formulating the form of modules that correspond to its maxims, the researchers felt the need to develop modules that can help counselor in order to shape the understanding of students is how to make a conducive environment for students so that social relationships pupils more well with the ability of self-regulation in social relations. to be given to the student module, delivery of services by counselors more varied.

\section{Method}

This study is a research \& development (research \& development). Development procedures applied in this study followed the steps of developing the model of ADDIE covering Analyze, Design, Development, Implementation, and Evaluation (Molenda, 2003). Product development activity conducted by researchers is through feasibility studies by experts, and the degree of the practicality by the counselor. Subjects tested in this study consisted of experts in the field of guidance and counseling consisting of three people to conduct feasibility studies on the product, and labor practitioner's counselor is composed of three people to assess the degree of the practicality test of the product that has been designed. Collecting data in this study using a scale, a questionnaire. Collected data is processed descriptively to portray the characteristics of the distribution of scores each respondent to define the category of product test results. In addition, the study also using nonparametric statistical test by using Kendall's concordance coefficient W.

\section{Results and Discussions}

Based on the results, it can be disclosed that by testing the viability of the development phase conducted by experts of the module counseling on student self-regulation in social relations overall assessment given to the product in the category decent value with a percentage of $74.4 \%$ is feasible in the category High School (SMA), once perfected in accordance with the input of experts so that the resulting module on self-regulation counseling students in social relationships as a result of product and ready to be implemented and tested keterpakaian in school by counseling teachers or counselors.

Furthermore, based on the test results Kendall's concordance coefficient W, to the expert judgment obtained probability equal to 0.006 . Thus, it can be said that there is alignment/ conformity assessment of the three experts on product research.

At the stage of implementation by the counselor, degree of the practicality test results obtained with a percentage value of $82 \%$ with a high category. This means that the assessment given by the counselor about compiled modules can be applied or used by the counselor at school. Then through the test Kendall's concordance coefficient $\mathrm{W}$, obtained a probability of 0.010 means that there is alignment/conformity assessment of guidance and counseling third counselor to product assessment.

The resulting product development research is a prototype module on self-regulation counseling students in social relationships as well as instructions for the use of modules counselors into one integral part. With the module counseling on student self-regulation of social relationships can improve the effectiveness of 


\section{Development of guidance and counseling module on self-regulation of students in social relations}

counseling services in the social field. Module development counseling on student self-regulation in social relations developed in the research covers several aspects.

\section{Modul Self Regulation Counseling on Students in Social Relations}

Products produced in this study include use guidelines module counseling on self-regulation of students in social relations for counselor. Modules counseling on self-regulation of students in social relationships for high school students who are both a unified whole and integral in this thesis, This product is named Module Counseling on Self Regulation in Social Relations. In developing this product, researchers guided by the measures contained in the ADDIE model of which is Analyze, Design, Development, Implementation, and Evaluation. From the results presented at the stage of development known that the products have reached the criteria drafted viable content/construct by experts in the field of guidance and counseling. This is evidenced by the percentage rating of 74 .

Feasibility value given by experts in the field of guidance and counseling is a value based on the objectivity of the content contained in the product. Objectivity can be evidenced by looking at the test results statistically using Kendall's concordance coefficient test. From the test results it was found that the degree of fit/alignment given ratings indicate a strong relationship between the expert with the acquisition probability 0.006 .

In general, the modules guide counseling on self-regulation in social relations student to counselor on aspects of the terms of reference drawn up has reached an adequate level of eligibility. Aspects foundation on which module is used to compile the module comes from studies that support the development goals. Further to the beneficial aspects the module is in conformity with the purpose of development. Beyond basic competency mapping aspects and indicators are in accordance with the materials developed. In the aspect of the material composition and interrelationships of matter that has been systematically formulated and interrelated. The support material used in the module is easily available and simple to use tool. In the aspect of general instructions to learn the modules in accordance with the direction of development. Then in the aspect of service plans contained in the modules are easy to understand and implement. Last on aspects of the material on the modules easily understood bycounselor and high school students in the school.

Further modules on self-regulation counseling students in social relationships for high school students on aspects of module description and a description of the initial behavior can be understood by students, on aspects of basic competencies and indicators are in accordance with the materials developed. Then for the purpose and importance of studying the aspects defined modules have been developed in accordance with the direction, the aspect of the discussion sequence module has been systematic and easy to understand, in the aspect of the module targets are in accordance with the characteristics of the development of high school students. Furthermore, in the aspect of use of the guidance is quite clear and easy to understand, the materials developed are already referring to the goal of developing this module as well as the moral message of the module is already in sync with the material provided.

In addition, the assessment given by experts on 8 indicators modules developed no show ratings below industry standards. This further reinforces that the module counseling on student self-regulation in social relations viable construct to be used bycounselor in an effort to increase students' understanding of selfregulation in social relations. This has relevance with the opinion Ward (in Suratsih, 2010: 15) on the characteristics of the module that "module is not a complete device, but that is absolutely there is a sheet instructional (as outlined in the learning tasks in each module), which is steering and students learn how to achieve the learning objectives". Furthermore, according to Sudjana and Rival (2001: 133).

Furthermore, the modules that have been validated by experts in the field of guidance and counseling is getting better after an assessment of counselor, the users. This is evident from the percentage of votes in the amount of $74.4 \%$, which means that the modules developed has shown excellent results to be accepted and used by counselor. Thus the entire section of research products in the form of modules counseling on student self-regulation of social relationships otherwise good and appropriate for use in schools at the high school level. 


\section{Degree of The Practicality Level Counseling on The Self Regulatory Students in Social Relations}

The research findings in order to determine the level of practicality product illustrates that the module counseling on student self-regulation in social relations show a good practicality bycounselor to improve students self regulation in social relations. Park and Sperling (2012) state that students will experience failure when they are unable to regulate themselves. Therefore, consistency in self regulation is needed. The way of such an issue is how students manage their daily activities in order to complete the tasks both their own task and social relationship. It is relevant to Ward's opinion (in Suratsih, 2010: 15) on the characteristics of the modules that: To be able to carry out tasks, help teachers to students is indispensable. Help is meant is the teacher's role is not just a teacher as informator in the learning process of students, but all the teacher's role: organizers, facilitators, conductors, initiator, motivator, mediators, evaluators, and others.

This exposed the fact that the overall assessment was supported by a percentage of $83 \%$ of products are included in the category of very high ratings, it can be interpreted that the counselors can practice counseling module on self-regulation of students in social relations. In addition, based on statistical analysis using Kendall's concordance coefficient test known level of alignment / conformity assessment provided indicating a strong relationship between counselor with a probability of acquisition of 0,010 .

Thus the research products in the form of counseling moduleon student's self-regulation in social relations can be practically done by counselors at the school. The use of this module will encourage students to be able to regulate themselves well in social relations. Such a service will be more focused on students while counselor only functions as a facilitator. It is in accordance with Asyhar (2011) who explains that by using module, students can learn at each others' pace and learn more independently. Thus, the product of this research in the form of module about students self-regulation in social relations can be applied by counselors in schools.

\section{Conclusions}

Based on the findings and discussion, it can be deduced that module on self-regulation of students in the social relations that are in decent category. It means that the experts agree that the modules are arranged feasible to be implemented or used counselors in providing services to students. Then, degree of the practicality level modules counseling on student self-regulation in social relations are at a high category. That is, that the counseling and guidance modules to enhance the ability of self-regulation in social relations can be used as a medium in guidance and counseling services.

\section{Acknowledgments}

Based on the conclusions, recommendation will be given to counselors and next researchers. For counselors, they can use the counseling module to encourage students to have good social relations. For next researchers, they can develop the module in a wider scope.

\section{References}

Ahmadi. (2007). Psikologi Sosial. Rineka Cipta. Jakarta.

Asyhar, R (2011). Kreatif Mengembangkan Media Pembelajaran. Jakarta: Gaung Persada Press.

Chairani, L. (2010). Psikologi Santri Penghafal Al-Quran Peranan Regulasi Diri (Vol. 1). Pustaka Pelajar.

Cleary, T. J., \& Zimmerman, B. J. (2004). Self-regulation empowerment program: A school-based program to enhance self-regulated and self-motivated cycles of student learning. Psychology in the Schools, 41(5), 537550 .

Depdiknas. (2008). Penulisan Modul. Jakarta: Ditjen PMPTK.

Feldman, P.O. (2009). Human Development: Perkembangan Manusia, Edisi 10 Buku 1. Jakarta: Salemba Humanika.

Florez, I. R. (2011). Developing young children's self-regulation through everyday experiences. YC Young Children, 66(4), 46.

Hendri, E. (2008). Implementasi Psikologi dalam Pembelajaran Sain di SD. Available: http://tulisanterkini.com/artikel/pendidikan/3180-implementasi-psikologi-dalam-pembelajaran-sain-di-

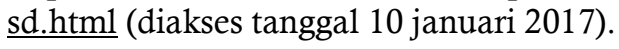


Khuziakhmetov, A.N., Shafikova, G.R dan Kapranova, V.A. (2015). Conditions of Educational Environment for The Development of Teenagers' Moral Relations. International Journal of Environmental \& Science Education 10(4): 515-521.

Molenda, M. (2003). In search of the elusive ADDIE model. Performance improvement, 42(5), 34-37.

Park, S. W., \& Sperling, R.A. (2012). Academic procrastinatorsandtheir self- regulation. Psychology, 3(01), 12.

Sudjana, N dan Rivai, A. (2001). Teknologi Pengajaran. Bandung: Sinar Baru Algensindo.

Suhendra, M. Neviyarni S \&Riska Ahmad. (2016). Kontribusi Motivasi Berprestasi terhadap Regulasi Diri siswa Membolos di Madrasah Aliyah Negeri 2 Payakumbuh serta Implikasinya terhadap Layanan Bimbingan dan Konseling. Jurnal Konselor. 5 (2): 124-132.

Suratsih. (2010). "Pengembangan Modul Pembelajaran Biologi Berbasis PotensiLokal dalam Kerangka Implementasi KTSP SMA di Yogyakarta".Laporan Hasil Penelitian tidak diterbitkan. Yogyakarta: UniversitasNegeri Yogyakarta.

Walgito, B. (2001). Psikologi Sosial. Yogyakarta: Penerbit Andi.

Zimmerman dan Martinez-Pons. (1989). A View of Student Self Regulated Academic Learning Social Cognitive Assumptions Triadic Reciprocality. Journal of Educational Psychology,82 (1).

Susanto, H. (2006). Pengembangan Kemampuan Self Regulation untuk Meningkatkan Keberhasilan Akademik Siswa. Jurnal Pendidikan Penabur. 5(7):64-71. 